\title{
Incidence of Unusual Formation of the Median Nerve in Thai-Northeast Embalmed Cadavers
}

\author{
Incidencia de la Formación Inusual del Nervio Mediano en \\ Cadáveres Embalsamados del Noreste de Tailandia
}

\begin{abstract}
Malivalaya Namking ${ }^{1}$; Arada Chaiyamoon'; Wunnee Chaijaroonkhanarak'; Kimaporn Khamanarong'; Worawut Woraputtaporn ${ }^{1}$ \& Sitthichai Iamsaard $^{1}$
\end{abstract}

NAMKING, M.; CHAIYAMOON, A.; CHAIJAROONKHANARAK, W.; KHAMANARONG, K.; WORAPUTTAPORN, W. \& IAMSAARD, S. Incidence of unusual formation of the median nerve in Thai-Northeast embalmed cadavers. Int. J. Morphol., 35(1):52$55,2017$.

SUMMARY: This study aimed to investigate the incidence of unusual formation of the median nerve in Thai cadavers. Two hundred and ninety-two upper limbs were dissected and observed. The results showed that 5 out of 292 (1.71\%) arms had unusual splitting of median nerve that supplied the flexor arm muscles. Concomitantly, the musculocutaneous nerve was absent. In 4 out of 5 variant arms ( $80 \%$ or $1.37 \%$ of total upper limbs), each median nerve was unusually formed by 3 roots; the first and second roots were from lateral cord and the third one from medial cord. The union of the second lateral and medial roots to become a median nerve distantly extended in the arm. The second lateral roots gave off small muscular branches to the upper part of flexor arm muscles. Knowledge of such anatomical variations is helpful for surgeons in performing of brachial plexus surgery.

KEY WORDS: Anatomical ariation; Median nerve; Upper limbs; Thai cadavers.

\section{INTRODUCTION}

Anatomical variations of the axillary region including muscles, median nerve and musculocutaneous nerve have clinical significance to surgeons, radiologists and anatomists for consideration in some clinical applications such as injured nerve transfer and brachial plexus surgery (Choi et al., 2002; Budhiraja et al., 2011a, b \& Iamsaard et al., 2012a,b). Basically, the median nerve is a branch of brachial plexus originating by the union of a lateral root from lateral cord and a medial root from medial cord. Median nerve usually branches off and supplies the flexor muscles of forearm. It usually does not give any branches to supply the brachial muscles (Drake et al., 2005). However, the unusual distribution and formation of median nerve in the upper limbs can be found during routine dissection of brachial plexus in teaching of the medical students as documented in previous reports (Table I). This variation has been described by various authors but quite different in frequency incidence and races (summarized in Table. I). Although many investigators have already described some unusual formations of median nerve (Choi et al.; Vollala et al., 2005; Saralaya et al., 2009; Jelev \& Georgiev, 2009; Budhiraja et al., 2011a, b \& Sarala et al.,
2011), such variant incidence has never been documented in Thai-Northeast (Isaan) population.

\section{MATERIAL AND METHOD}

Two hundred and ninety-two arms or upper limbs of Thai-Northeast embalmed cadavers obtained from the Medical Gross Anatomy Laboratory in the department of Anatomy, Faculty of medicine, Khon Kaen University, ranging in age from 19 to 96 years, were investigated. The axilla and arm regions were carefully dissected and retracted to observe the distributions of brachial plexus. The unusual distribution and formation of the median nerve including its relation to the musculocutaneous nerve were photographed and recorded. The data collection was performed from 2012 to 2014. The incidence of axillary nerve variation was tabulated as percentages of all samples $(n=292)$. This study was approved by the Human Ethics Committee of The Office Human Research of Khon Kaen University, Thailand, based on the

${ }^{1}$ Department of Anatomy, Faculty of Medicine, Khon Kaen University, 123 Mittraphap Road, Maung, District, Khon Kaen, 40002, Thailand. 
Ethics of Human Experimentation of the National Research Council of Thailand (Reference number: HE531210).

\section{RESULTS}

In 292 arms, we found that 5 upper limbs $(1.71 \%)$ had some unusual splitting nerve branches of median nerve in the arms (Fig. 1). These small nerve branches indeed innervate the mostly distal part of biceps brachii and brachialis muscles before they terminate as the lateral cutaneous nerve of the foream (Fig. 1).

Concomitantly, the musculocutaneous nerve was absent (Fig. 1). Interestingly, we found that each median nerve of 4 out in 5 variant upper limbs ( $80 \%$ of unusual cases or $1.37 \%$ of total arms observed) had 3 variant formations of nerve roots (Fig. 1). Two of them (first and second lateral roots of the median nerve) come from the lateral cord (LC) whereas the rest nerve (the third medial root of median nerve) originated from the medial cord (MC) (Fig. 1). It was noted that the point of union between the second lateral and a medial roots to form a median nerve distantly extended in the arm (Fig. 1). In these unusual specimens, the second lateral roots of median nerve gave off small muscular branches to supply the upper part of biceps brachii muscle (Fig. 1).

\section{DISCUSSION}

The nerve variation of upper limbs especially in brachial plexus was first described by Walsh (1877). Then, numerous authors have reported the number of cases and incidences of unusual median nerve information found in their own populations (summarized in Table I). The variations of the median nerve distributions are concerned to have clinical significance to surgeons, radiologists and anatomists in the injured nerve transfer and brachial plexus surgery. The incidences of unusual formation of median nerve have been documented in populations of Americans (Walsh; Uzun \& Seelig, 2001), Slovakians (Haviarova et al., 2001), British (Choi et al.), Indians (Chauhan \& Roy, 2002; Goyal et al., 2005; Anrkooli et al., 2007; Budhiraja et al., 2009; Saralaya et al.; Aggarwal et al., 2010; Datta et al., 2011; Sarala et al., 2011; Budhiraja et al., 2011a,b and 2012; Parchand \& Patil, 2013), Saudi Arabians (Saeed \& Rufai, 2003), Egyptians (Beheiry, 2004), Iranians (Anrkooli et al.), Portuguese (Pais et al., 2010), Kenyas (Ongeti et al., 2012), and Singaporeans (Parchand \& Patil), respectively. The present study is the first report demonstrating the incidence of unusual distribution and concomitant formation of the median nerve in Thai's Thai-Northeast cadavers (Fig. 1).

In the literatures (Table I), it was found that the most incidence of unusual formation of the median nerve was observed in British $(46.64 \%)$ and Indians $(26.4 \%)$. Interestingly, both case reports and incidences of unusual formation of the median nerve were mostly documented in Indian race (Table I). Although the number of upper limbs of American sample was highest (350 arms), the percentage of such variation was lowest $(0.57 \%)$ as compared to other races (Table I). We found that this variant incidence was extremely varied to each other. However, our incidence observed in present study $(1.71 \%)$ was much closed to that in Egyptians (1.7\%) reported by Beheiry.

The knowledge of such anatomical variations could be used to explain a high median nerve paralysis in a patient presenting with weakness of forearm flexion and supination.
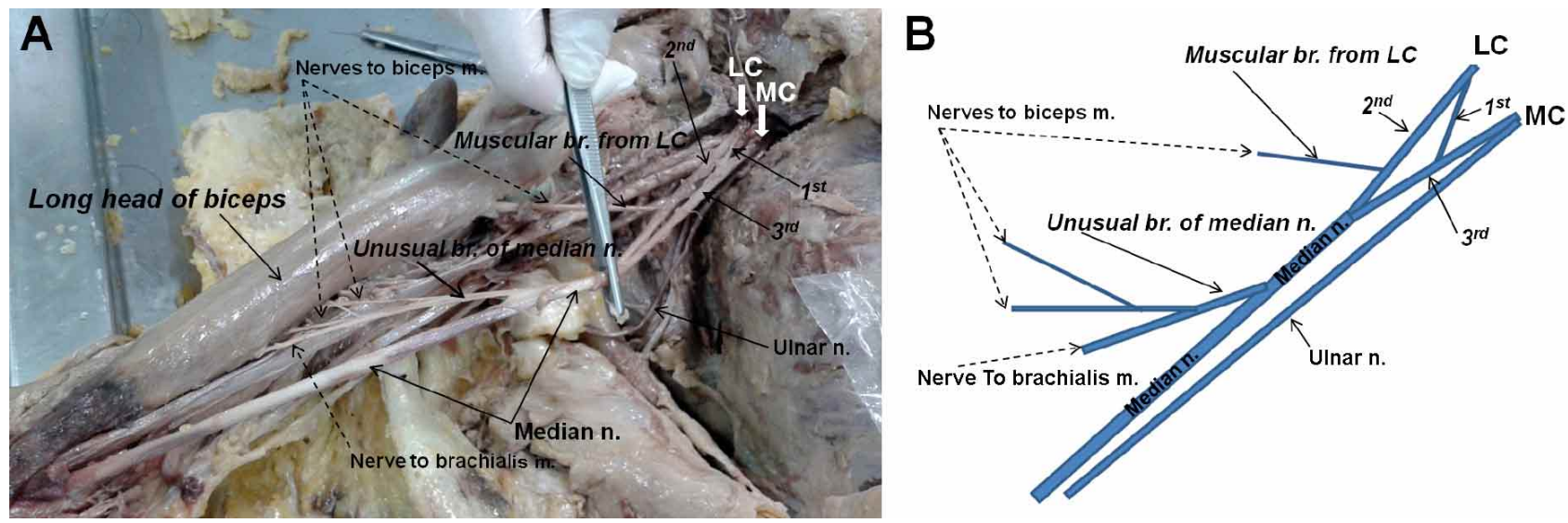

Fig. 1. Representative photograph (A) and schematic diagram (B) showing unusual distribution and concomitant formation of the median nerve in the right arm. LC, lateral cord of brachial plexus; MC, medial cord of brachial plexus; $\mathrm{m}$, muscle; $\mathrm{n}$, nerve; $1^{\text {st }}$, first lateral root of median nerve; $2^{\text {nd }}$, second lateral root of median nerve; $3^{\text {rd }}$, medial root of median nerve. 
Table I. The unusual formation of median nerve in the literatures.

\begin{tabular}{|c|c|c|c|c|}
\hline Races & $\begin{array}{c}\text { No. of } \\
\text { upper limbs }\end{array}$ & \multicolumn{2}{|c|}{$\begin{array}{l}\text { Unusual for mation of } \\
\text { No. median Percentage }\end{array}$} & References \\
\hline Americans & 350 & 2 & $0.57 \%$ & Walsh, 1877 \\
\hline Slovakians & ND & 1 & ND & Haviarova et al.,2001 \\
\hline Americans & 40 & 2 & $5 \%$ & Uzun \& Seelig, 2001 \\
\hline Indians & ND & 1 & ND & Chauhan \& Roy, 2002 \\
\hline British & 276 & 64 & $46.4 \%$ & Choi et al., 2002 \\
\hline Saudi Arabians & ND & 1 & ND & Saeed \& Rufai, 2003 \\
\hline Egyptians & 60 & 1 & $1.7 \%$ & Beheiry, 2004 \\
\hline Indians & ND & 2 & ND & Goyal et al., 2005 \\
\hline Indians & ND & 1 & ND & Nayak et al., 2005 \\
\hline Iranians & ND & 1 & ND & Anrkooli et al., 2007 \\
\hline Indians & ND & 1 & ND & Budhiraja et al., 2009 \\
\hline Indians & ND & 1 & ND & Saralaya et al., 2009 \\
\hline Portuguese & ND & 1 & ND & Pais et al., 2010 \\
\hline Indians & ND & 1 & ND & Aggarwal et al., 2010 \\
\hline Indians & ND & 1 & ND & Datta et al., 2011 \\
\hline Indians & 196 & 44 & $22.4 \%$ & Budhiraja et al., 2011a \\
\hline Indians & 116 & 13 & $11.2 \%$ & Budhiraja et al., 2011b \\
\hline Kenyas & ND & 2 & ND & Ongeti et al., 2012 \\
\hline Indians & 174 & 46 & $26.4 \%$ & Budhiraja et al., 2012 \\
\hline Singaporeans & ND & 2 & $\mathrm{ND}$ & Thwin et al., 2012 \\
\hline Indians & ND & 1 & ND & Parchand \& Patil, 2013 \\
\hline $\begin{array}{l}\text { Thais (Northeast; Isaan) } \\
N D=\text { Not determined }\end{array}$ & 292 & 5 & $1.71 \%$ & Namking et al., (present study) \\
\hline
\end{tabular}

In addition, surgeons should also be aware of this type of variation in performing the brachial plexus surgery to avoid nerve injury.

\section{ACKNOWLEDGMENTS}

We would like to thank the Department of Anatomy, Faculty of Medicine, Khon Kaen University, for providing the materials and financial supports.

\section{NAMKING, M.; CHAIYAMOON, A.;} CHAIJAROONKHANARAK, W.; KHAMANARONG, K.; WORAPUTTAPORN, W. \& IAMSAARD, S. Incidencia de la formación inusual del nervio mediano en cadáveres embalsamados del noreste de Tailandia. Int. J. Morphol., 35(1):47-51, 2017.

RESUMEN: Este estudio tuvo como objetivo investigar la incidencia en la formación inusual del nervio mediano en cadáveres tailandeses. Se disecaron y observaron 292 miembros superiores. En 5 casos $(1,71 \%)$ se presentó una división inusual del nervio mediano que suministraba los nervios para los músculos flexores del brazo. Concomitantemente, el nervio musculocutáneo estaba ausente. En 4 de los 5 casos (80\% o 1,37\% del total de los miembros superiores), cada nervio mediano se formó por 3 raíces; la primera y segunda raíces procedían del fascículo lateral y la tercera del fascículo medial. La unión de la segundas raíces lateral y medial formaban el nervio mediano distalmente en el brazo. Las segundas raíces laterales daban pequeños ramos musculares a la parte superior de los músculos flexores del brazo. El conocimiento de tales variaciones anatómicas es útil para los cirujanos en la realización de la cirugía del plexo braquial.

PALABRAS CLAVE: Variación anatómica; Nervio mediano; Miembros superiores; Cadáveres tailandeses.

\section{REFERENCES}

Anrkooli, J.; Mahmoudian, A. R. \& Karimfar, M. H. Arare bilateral variation in the formation of median nerve. J. Iran. Anat. Sci., 4(17):383-7, 2007.

Aggarwal, A.; Puri, N.; Aggarwal, A. K.; Harjeet, K. \& Sahni, D. Anatomical variation in formation of brachial plexus and its branching. Surg. Radiol. Anat., 32(9):891-4, 2010.

Beheiry, E. E. Anatomical variations of the median nerve distribution and communication in the arm. Folia. Morphol. (Warsz.), 63(3):313-8, 2004.

Budhiraja, V.; Rastogi, R.; Khare, S. \& Jain, S. A rare variation in the formation of the lateral cord and median nerve of brachial plexus - A case report. People's J. Sci. Res., 2(1):17-18, 2009.

Budhiraja, V.; Rastogi, R. \& Asthana, A. K. Anatomical variations of the median nerve formation: embryological and clinical correlation. $J$. 
Morphol. Sci., 28(4):283-6, 2011a.

Budhiraja, V.; Rastogi, R.; Asthana, A. K; Sinha, P.; Krishna, A. \& Trivedi, V. Concurrent variations of median and musculocutaneous nerves and their clinical correlation--a cadaveric study. Ital. J. Anat. Embryol., 116(2):67-72, $2011 \mathrm{~b}$.

Budhiraja, V.; Rastogi, R. \& Asthana, A. K. Variations in the formation of the median nerve and its clinical correlation. Folia Morphol. (Warsz.), 71(1):28-30, 2012.

Chauhan, R. \& Roy, T.S. Communication between the median and musculocutaneous nerve - A case report. J. Anat. Soc. India, 51(1):725, 2002.

Choi, D.; Rodríguez-Niedenführ, M.; Vázquez, T.; Parkin, I. \& Sañudo, J. R. Patterns of connections between the musculocutaneous and median nerves in the axilla and arm. Clin. Anat., 15(1):11-7, 2002.

Datta, I.; Ghoshal, A. K. \& Ray, A. Complete absence of lateral root of median nerve and communication of musculocutaneous nerve with median nerve--a case report. J. Indian Med. Assoc., 109(5):341-2, 2011.

Drake, R. L.; Vogl, W. \& Mitchell A. W. M. Gray's Anatomy for Students. Philadelphia, Elsevier/Churchill Livingstone, pp.661-3, 2005.

Goyal, N.; Harjeet \& Gupta, M. Bilateral variant contributions in the formation of median nerve. Surg. Radiol. Anat., 27(6):562-5, 2005.

Haviarova, Z.; Falougy, E.L.; Killingerova, A. Atypical course of the median nerve. Bratisl. Lek. Listy., 102(8):372-3, 2001.

Iamsaard, S.; Thunyaharn, N.; Chaisiwamongkol, K.; Boonruangsri, P.; Uabundit, N. \& Hipkaeo, W. Variant insertion of the teres major muscle. Anat. Cell Biol., 45(3):211-3, 2012a.

Iamsaard, S.; Uabundit, N.; Khamanarong, K.; Sripanidkulchai, K.; Chaiciwamongkol, K.; Namking, M.; Ratanasuwan, S.; Boonruangsri, P.; Hipkaeo, W. Duplicated axillary arch muscles arising from the latissimus dorsi. Anat. Cell Biol., 45(4):288-90, 2012b.

Jelev, L. \& Georgiev, G. P. Unusual high-origin of the pronator teres muscle from a Struthers' ligament coexisting with a variation of the musculocutaneous nerve. Rom. J. Morphol. Embryol., 50(3):497-9, 2009.

Ongeti, K.; Pulei, A.; Ogeng'o, J. \& Saidi, H. Unusual formation of the median nerve associated with the third head of biceps brachii. Clin. Anat., 25(8):961-2, 2012.

Pais, D.; Casal, D.; Santos, A. \& O'Neill, J. G. A variation in the origin of the median nerve associated with an unusual origin of the deep brachial artery. J. Morphol. Sci., 27(1):35-8, 2010.

Parchand, M. P. \& Patil, S. T. Absence of musculocutaneous nerve with variations in course and distribution of the median nerve. Anat. Sci. Int., 88(1):58-60, 2013.

Saeed, M. \& Rufai, A. A. Median and musculocutaneous nerves: variant formation and distribution. Clin. Anat., 16(5):453-7, 2003.

Saralaya, V.; Nayak, S. R.; Sequeira, S.; Madhyastha, S.; Krishnamurthy, A. \& D'Costa, S. An unusual tunnel formation in the arm and its clinical significance. Int. J. Anat. Var., 2:27-8, 2009.

Sarala, D. K. V.; Udhaya, K. \& Sudha, S. A study on the variations of median nerve formation in the south Indian population. Int. J. Anat. Sci., 2(1):7-10, 2011.

Thwin, S. S.; Zaini, F.; Than, M.; Lwin, S. \& Myint, M. Unusual variations of the lateral and posterior cords in a female cadaver. Singapore Med. J., 53(6):e128-30, 2012.

Uzun, A. \& Seelig, L. L. Jr. A variation in the formation of the median nerve: communicating branch between the musculocutaneous and median nerves in man. Folia Morphol (Warsz.), 60(2):99-101, 2001.

Vollala, V. R.; Raghunathan, D. \& Rodrigues, V. Nerve compressions in upper limb: a case report. Neuroanatomy, 4:35-6, 2005.

Walsh, J. F. The anatomy of the brachial plexus. Am. J. Med. Sci., 74:38797, 1877.

\section{Correspondences to: \\ Dr. Sitthichai lamsaard \\ Department of Anatomy \\ Faculty of Medicine \\ Khon Kaen University \\ 123 Mittraphap Road \\ Amphoe Muang \\ Khon Kaen 40002 \\ THAILAND}

\section{Telephone: +66-4336-3212 $+66-85-289-6363$ \\ Fax: $+66-4336-3212$}

Email: sittia@kku.ac.th

Received: 09-10-2015

Accepted: 23-11-2016 